\title{
Odontogenic Neoplasm
}

National Cancer Institute

\section{Source}

National Cancer Institute. Odontogenic Neoplasm. NCI Thesaurus. Code C3286.

A benign or malignant neoplasm arising from tooth-forming tissues. It occurs in the maxillofacial skeleton or the gingiva. Benign tumors are slow growing and are not associated with specific clinical symptoms. Pain is absent or slight. Malignant tumors are usually associated with rapid swelling and pain. 